\title{
Neural Substrates Underlying Interactions between Appetite Stress and Reward
}

\author{
John R.W. Menzies ${ }^{a}$ Karolina P Skibickab Suzanne L. Dickson ${ }^{b}$ \\ Gareth Leng ${ }^{\text {a }}$
}

${ }^{a}$ Centre for Integrative Physiology, School of Biomedical Sciences, University of Edinburgh, Edinburgh, UK, b Department of Physiology/Endocrinology, Institute of Neuroscience and Physiology, The Sahlgrenska Academy at the University of Gothenburg, Gothenburg, Sweden

\section{Key Words}

Stress $\cdot$ Reward $\cdot$ Vasopressin $\cdot$ Oxytocin $\cdot$ Ghrelin

\begin{abstract}
Neurobiological mechanisms that normally control food intake and energy expenditure can be overcome by environmental cues and by stress. Of particular importance is the influence of the mesolimbic reward pathway. In genetically susceptible individuals, problematic over-eating likely reflects a changing balance in the control exerted by homeostatic versus reward circuits that are strongly influenced by environmental factors such as stress. Both stress and activation of the reward pathway have been shown to increase food intake and promote a preference for palatable, high-energy foods. Recent research has focused on the important role of circulating and central neuropeptides that powerfully regulate the brain response to food cues. For example, ghrelin has a potent positive effect on the motivational aspects of food intake, and central oxytocin may be involved in satiety. Thus, the decision to eat, or indeed to over-eat, involves a complex integrated neurobiology that includes brain centres involved in energy balance, reward and stress and their regulation by metabolic and endocrine factors.
\end{abstract}

Copyright (c) 2012 S. Karger GmbH, Freiburg

\section{Introduction}

Weight gain, obesity and psychological stress are pervasive elements of modern developed societies. The consequences of obesity and their threat to long-term health have been disseminated widely. But in contrast to the prevalence of tobacco smoking, for example, which has been dropping steadily in the UK since the 1970s, obesity levels are high and 
rising, especially in children [1]. The rise in obesity reflects a strong drive to consume food, especially energy-dense fatty or sugary foods, that continues to be present even when in positive energy balance. It seems that our stressful, modern environment has the capacity to inundate intrinsic neural mechanisms that homeostatically regulate appetite and food intake. Some have called this our 'obesogenic' environment: an environment that somehow promotes an increase in food intake, primarily via the ready availability of high-energy foods, and simultaneously a decrease in energy expenditure [2].

It is clear that forces other than homeostatic energy balance and food availability must drive food intake in the face of a surplus energy store. For those of us wholive in the developed world at least, food supply is abundant, safe, varied and inexpensive. With virtually no counteracting drive to rein in our drive to eat (except perhaps social or health pressures at a cognitive level), an increase in obesity may be inevitable. Here we assess the potential contribution from two other important drives: the effect of stress on feeding behaviour and the rewarding properties of consuming energy-dense food. We examine the potential neural substrates that may underlie the alterations in food intake and feeding behaviours associated with reward and the exposure to stress.

\section{Modifying Food Intake: Established Targets}

Soon after the discovery of leptin, a cascade of research revealed the pivotal role of certain hypothalamic nuclei in the control of food intake and energy expenditure [3]. It was hoped that these neuronal pathways could be exploited to oppose the rising prevalence of diet-induced obesity and metabolic disorders in humans. However, it quickly became clear that only a very small minority of individuals suffering from obesity had tractable conditions, typically genetic deficiencies in leptin or other components of the orexigenic pathways (most notably melanocortin-4 receptor mutations [4]). Despite the clear success in treating those rare monogenetic disorders of appetite, a startling degree of redundancy is evident in the systems that control food intake. For most of us, these hypothalamic pathways may not provide a successful target for anti-obesity therapy. For example, a major population of orexigenic neurons in the arcuate nucleus of the hypothalamus expresses several neurotransmitters including neuropeptide Y (NPY) and agouti-related peptide (AgRP). Activation of these neurons (by ghrelin, for example), or activation of their downstream targets (by centrally administered NPY) in rodents normally evokes a strong feeding response [5]. Surprisingly, this feeding response is maintained in NPY-knockout mice [6], in AgRPknockout mice and even in double NPY/AgRP-knockout mice that lack these peptides throughout development to maturity [7]. Only complete ablation of NPY/AgRP neurons in adulthood leads to marked changes in feeding patterns and rapid starvation [8]. These data give one example highlighting the redundancy of hypothalamic orexigenic drive. This drive depends on inputs that signal the physiological state of the organism: chronic energy stores via leptin and insulin and more acute nutritional state via gut-brain peptides such as ghrelin and PYY(3-36).

A second problem is that pathways known to have a pivotal role in appetite regulation also have a major influence on other physiological systems. For example, the arcuate nucleus contains a population of neurones that is the main source of the key anorexigenic peptide alpha melanocyte stimulating hormone $(\alpha \mathrm{MSH})$; this, signalling mainly through hypothalamic MC4 receptors, is a very potent inhibitor of feeding and was a major target of efforts to develop pharmaceutical approaches to moderating appetite. However, the same neurones, again acting via $\alpha \mathrm{MSH}$ release and its effects on MC4 receptors, are also a potent stimulator of sexual behaviour [9]. It seems likely that the motivation to eat and the 
motivation to reproduce, being mutually exclusive, are reciprocally regulated - so any attempt to intervene pharmacologically at this level may have important consequences for other behaviours.

The hypothalamic orexigenic pathways are complex, and, despite more than a decade of research, few drug targets have been delineated and even fewer therapeutic avenues have been utilised successfully. It may be of value to broaden our attention from the neural systems that monitor and control energy intake and expenditure to include other systems involved in changes in appetite in response to stress and our drive to experience rewarding behaviour.

\section{Effects of Stress on Appetite}

Stress is generally defined as an external challenge to an organism's physiological equilibrium. A stressful stimulus requires the organism to adapt its physiology or behaviour to counter the stressor's harmful effects. During acute stress, the major adaptive pathway activated is the hypothalamic-pituitary-adrenal (HPA) axis [10]. The paraventricular nucleus (PVN) of the hypothalamus integrates inputs from the periphery and other brain regions and is activated during stressful stimuli. Classically, corticotrophin-releasing hormone (CRH) is secreted from neuroendocrine cells of the PVN via the median eminence and into the portal blood supply. CRH regulates the release of adrenocorticotropic hormone (ACTH) from anterior pituitary corticotrophs. ACTH subsequently acts on the adrenal cortex to promote glucocorticoid secretion which, in turn, has several dramatic but short-term effects to enhance metabolism and promote attentiveness and preparedness in the organism. Typical acute effects of glucocorticoid release are conservation of blood glucose, an increased blood pressure and a diversion of blood flow from the gastrointestinal tract to the skeletal muscles and brain. These acute effects are terminated by the negative feedback effects of glucocorticoids at both the anterior pituitary and the brain - including especially the PVN, where glucocorticoids trigger the production of endocannabinoids by the CRH neurones, which in turn act presynaptically to suppress afferent input to those neurones.

Given that the objective of the stress response is to preserve homeostasis in the short term, it may be counterintuitive to suppose that stress could increase food intake. During stress, time spent searching for, consuming and digesting food may be better spent defending against the stressor itself. Indeed, many studies in rats have demonstrated that chronic stressors such as daily restraint or immobilisation decrease food intake and that this is dependent on the duration and intensity of the stress [11]. However, glucocorticoid administration stimulates palatable food intake in adrenalectomised rats [12], and stressful stimuli have been shown to have orexigenic effects. If offered palatable, high-energy food in addition to the normal laboratory diet, rats undergoing dietary restriction increase their intake of palatable food in response to chronic foot shock stress [13]. Similarly, rats experiencing a chronic tail pinch stress gain more weight when offered a palatable, high-energy diet compared to animals on a standard diet [14].

Like physical stressors, other types of stress have a variety of effects on appetite including an increase in food intake and body weight. Social stress in humans is considered to be commonplace in modern society, and a commonly used model of social stress in rats is the 'visible burrow model' [15]. In this model, a group of male rats is housed together, and a hierarchy naturally develops where one male rat becomes dominant and the others become subordinate. During this process all of the rats suffer stress and have a reduced food intake. However, once the hierarchy is established, subordinate animals become further stressed, displaying a higher basal level of plasma corticosterone than the dominant animal. Subor- 
dinate animals' food intake remains reduced, and they lose body weight, whereas the dominant rat restores its food intake and tends to maintain body weight. Upon termination of the chronic social stress, both dominant and subordinate animals increase their body weight but only the subordinate animals are hyperphagic; thus, after recovery from social stress, subordinate rats have a larger increase in adipose tissue than the dominant animal. This effect is amplified when rats are fed a high-fat diet [16], suggesting that a consequence of chronic social stress is to increase food intake in a way that favours the intake of highenergy foods, and that this can lead to adiposity.

\section{The Importance of Reward in Appetite}

Many activities necessary to life and its perpetuation, such as sexual behaviour and eating, are pleasurable. The pleasure associated with these behaviours influences future behaviour, making an organism more likely to engage in these activities again. Interest is now increasing in the neural mechanisms that underlie these non-homeostatic, hedonistic aspects of energy balance. Energy-dense foods are powerful rewards and their rewarding properties encourage their consumption even during positive energy balance. Repeated consumption can lead to conditioning: a learned association between the food stimuli (taste, smell, texture) and an expected reward [17]. Indeed, obese individuals show a stronger preference for palatable (high-fat, high-carbohydrate) food than lean individuals, presumably due to a strengthened experience of reward [18]. The evolutionary advantages of these drives are obvious; they alert an organism to the presence of high-energy foods and encourage the accumulation of energy stores during times of increased availability. However, for humans in the developed world at least, this beneficial drive has transformed into a burden.

Reward mechanisms primarily involve the mesolimbic system. The role of dopamine neurones in the mesolimbic pathway (ventral tegmental area (VTA) - nucleus accumbens (NAcc) - frontal cortex/amygdala) and the control of motivation to eat and drink has been investigated extensively [19]. As well as projecting to the frontal cortex, the shell of the NAc sends inhibitory inputs to the lateral hypothalamus [20]. Palatable food stimulates the release of dopamine in the mesolimbic system and results in repeated self-administration, in other words hyperphagia [21]. It has been suggested that low dopamine release may be related to obesity [22] and that the mesolimbic system may be dysregulated in obesity, such that a state of 'reward deficiency' exists [23]. In support of this hypothesis, rats fed an unrestricted palatable diet develop a reduced sensitivity to electrical self-stimulation of the mesolimbic pathway, suggesting that frequent intense activation of the reward pathway by feeding leads to a desensitisation or dysregulation of that pathway. Furthermore, these rats exhibit diet-induced hyperphagia even when conditioned to expect a painful foot shock during the feeding session [24], indicating that they receive a sufficient reward from palatable food intake to overcome the threat of a concurrent aversive stimulus. A fundamental role for the dopaminergic mesolimbic system is revealed in dopamine-deficient mice (created by deleting tyrosine hydroxylase globally then restoring the enzyme only in noradrenergic neurones). These transgenic mice are hypoactive and aphagic [25], and their aphagia results in death from starvation in a few weeks. These effects can be prevented by L-DOPA administration; treated dopamine-deficient mice become hyperactive compared to controls and begin to eat voraciously. Similarly, deletion of both dopamine D1 and D2 receptor leads to death by starvation after a few weeks, even in animals nursed by hand [26]. 


\section{Ghrelin, Leptin and a Link between Stress, Reward and Appetite}

The reward pathway is modifiable by several peptides that are involved in food intake (fig. 1). Two of the key peptides involved in regulating food intake are ghrelin, an orexigenic hormone secreted from the stomach in progressively increasing amounts since the last meal, and leptin, an appetite-inhibiting hormone secreted from adipocytes which circulates at concentrations proportional to total body fat mass. The VTA expresses ghrelin receptors [27], and ghrelin administration to the VTA causes dopamine release [28] and increases in food intake [29], notably the intake of (and preference for) rewarding/palatable food [30]. Indeed, central ghrelin signalling, via GHS-R1A, appears to be important for food reward [30], for motivated behaviour for rewarding foods [31, 32] and also for the reward associated with artificial rewards such as alcohol [33], cocaine and amphetamine [34]. In brain slices, VTA dopamine neurones are excited in vitro by ghrelin [29]. In contrast, ghrelin can potentiate [28, 29] or, depending on feeding state, inhibit [35] dopamine signalling in the mesolimbic system, a complementary effect to that seen in the hypothalamus. Thus, within the mesolimbic system ghrelin targets a key pathway involved in reward reinforcement, especially in the motivation for natural and artificial rewards.

Besides its well-known effects at sites in the hypothalamic arcuate nucleus, leptin has also been suggested to act upon reward systems involved in the hedonic control of food intake. Dopamine neurones in the VTA also express receptors for leptin [36]; the actions of leptin are inhibitory (at least in brain slices in vitro) and, as suggested by a conditioned place preference test, are independent of leptin's effects on feeding in the hypothalamus. Leptin suppresses dopamine signalling in the mesolimbic system via leptin receptor-expressing $\mathrm{LH}$ neurons that innervate the VTA [37,38], and administration of exogenous leptin attenuates self-stimulation of NAcc dopamine release [39]. Selective knockout of leptin receptor in the lateral hypothalamus (one of the targets of NAcc output) of rats fed a high-fat diet causes an increase in food intake, body weight and adiposity. Selective knockout of leptin receptors in the midbrain restored the palatable diet-induced suppression of NAcc dopamine content [40]. In other words, these data suggest that leptin acts at the mesolimbic system to restrain responses to food rewards, thereby suppressing the rewarding properties of feeding.

Acute stress, including psychological [41] and starvation stress [42], increases plasma ghrelin levels. Conversely, ghrelin, at concentrations within the normal physiological range, stimulates the HPA axis, increasing hypothalamic CRF mRNA expression and raising plasma corticosterone levels [42]. It has been suggested that glucocorticoids may have permissive effects for ghrelin's orexigenic and fat-accumulating effects [43]. Anxiety and depression are often associated with stress. In rodents, acute peripheral injections of ghrelin as well as central injections (into the brain ventricles or into specific parenchymal targets such as the amygdala, dorsal raphe nucleus and hippocampus] induce anxiety-like behaviour [42, 44, 45]. Furthermore, suppression of central ghrelin action by administration of antisense DNA for ghrelin causes a decrease in anxiety- and depression-like behaviour in rats [46]. Lutter and colleagues [47], however, reported a decrease in anxiety- and depression-like behaviour in mice after peripheral ghrelin injection as well as after starvation. Given the chronicity of mood disorders in humans, the recent finding that chronic central ghrelin treatment of rats increases anxiety- and depression-like behaviour may be especially relevant [48].

Elements of the HPA axis also express the leptin receptor, and there is evidence that leptin can suppress the stress response by acting at the hypothalamus and the adrenal gland. Leptin reduces $\mathrm{CRH}$ release from the mouse hy pothalamus in vitro (but has no effect on ACTH release from primary cultures of rat pituitary) [49] and inhibits basal and ACTH-evoked glucocorticoid release from bovine adrenocortical cells in vitro [50]. An increased sensitivity of the HPA axis has also been observed in the leptin-receptor deficient Zucker rat [51]. Glucocorti- 


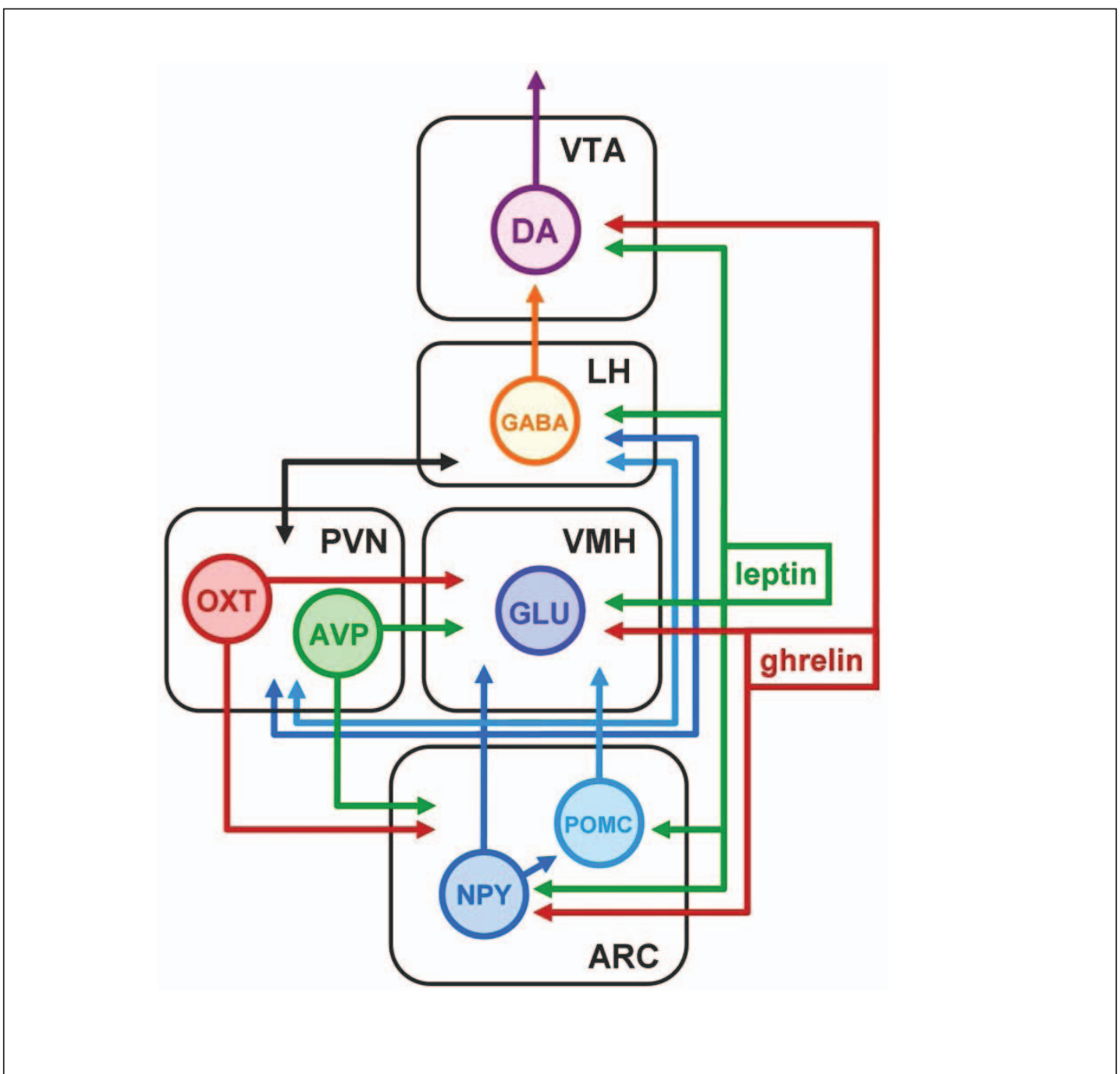

Fig. 1. A schematic representation of some of the brain nuclei involved in food intake, stress and reward. In terms of energy balance, the best-characterised hypothalamic nucleus is the arcuate nucleus (ARC). The ARC expresses at least two functionally distinct populations of neurones. NPY neurones (which also express AgRP and GABA) are considered orexigenic. POMC neurones (which, in the arcuate, express CART and the POMC gene product $\alpha \mathrm{MSH}$ ) are considered anorexigenic. Both populations project to the hypothalamic paraventricular nucleus (PVN), the ventromedial hypothalamus (VMH) and the lateral hypothalamus (LH). Within the ARC, NPY/AgRP/GABA neurones directly inhibit POMC/CART neurones probably via local GABA release. Both ARC populations express receptors for leptin (released systemically from adipocytes) but sensitivity to ghrelin (released systemically from the stomach mucosa between meals) is restricted to NPY/AgRP/GABA neurones. Ghrelin and leptin both act at the predominantly glutamatergic (GLU) neurones of the VMH. GABAergic neurones of the LH also express leptin receptors. As well as its classical role in the release of corticotrophin-releasing hormone and activation of the HPA axis, the PVN also expresses oxytocin (OXT) and vasopressin (AVP) and releases both peptides centrally from a dendritic source. OXT and AVP can act at NPY/AgRP/GABA and POMC/CART neurones in the ARC and at the VMH. Apart from a leptin-sensitive LH projection to the VTA, the neuronal/neurohormonal networks linking the hypothalamus to the mesolimbic reward system are currently unclear, though dopaminergic (DA) neurones of the ventral tegmental area (VTA) involved in the reward pathway are sensitive to leptin and ghrelin. Other hypothalamic neurones not illustrated here are recognised to have a role in appetite, stress and reward. Notably, the orexin-expressing neurones of the lateral hypothalamus are involved in arousal and the motivation to eat and oxy tocin and vasopressin neurones of the supraoptic nucleus (SON) are also sensitive to leptin, ghrelin and $\alpha \mathrm{MSH}$. 
coids may have a reciprocal effect on circulating leptin levels, inhibiting levels in some human studies [52], but not in others [53]. In contrast to data showing an inhibitory effect of leptin on the stress response, lean humans generally show a reduced a HPA axis activation to various stressors compared to overweight individuals (who are likely to have higher plasma leptin levels than lean subjects). The mouse HPA axis is activated by leptin (increasing hypothalamic $\mathrm{CRH}$ and pituitary POMC mRNA and increasing circulating ACTH and corticosterone), though this effect is mediated by vasopressin acting via central V1a/b receptors [54] and thus may represent an alternative pathway that is perhaps more relevant to chronic stress.

\section{Vasopressin, Oxytocin and a Link between Stress, Reward and Appetite}

During chronic stress in rodents, a major phenotypic change occurs in a key element of the HPA axis. Neurones in the PVN change their phenotype from expressing CRH to expressing a different peptide: vasopressin. Thus, when rats are exposed daily to episodes of restraint stress, each episode produces an activation of the HPA axis that results in a surge of ACTH and corticosterone secretion; initially this reflects $\mathrm{CRH}$ release, and the cells that are activated in the PVN show a prompt increase in both CRH mRNA expression and in vasopressin mRNA expression. But with each repetition of the stress, the increase in CRH mRNA expression is attenuated, while the increase in vasopressin mRNA expression is sustained or strengthened. Vasopressin receptor (V1bR) expression is also upregulated in the target tissue, the pituitary corticotroph [55]. Vasopressin and the closely related peptide oxytocin have recently been found to have an unexpectedly strong link with appetite [56]. Indeed, in a microarray study of the PVN that looked specifically for genes whose expression was downregulated in fasting and then upregulated by leptin, oxytocin and vasopressin were two of the most responsive genes identified. [57, 58].

The PVN is a source of several neuropeptides associated with the termination of feeding and is considered an important hypothalamic nucleus in the satiety response as lesions of the PVN cause hyperphagia and obesity [59]. The PVN is innervated by both NPY- and $\alpha \mathrm{MSH}-$ containing fibres from the arcuate nucleus, and both oxytocin neurones and vasopressin neurones express MC4 receptors in abundance. V1aR-knockout mice have altered glucose homeostasis and are susceptible to diet-induced obesity [60]. Central (but not peripheral) administration of oxytocin in hibits feeding, even in fasted rats [61], and male, but not female, oxytocin receptor-deficient mice display late-onset obesity [62]. The activity of oxytocin neurones can be reduced by chronic high sucrose consumption [63] and oxytocin has been suggested to inhibit carbohydrate intake selectively [64].

Vasopressin and oxytocin receptors are present in many brain regions, including in the arcuate nucleus and the adjacent ventromedial nucleus (VMH) [65]. The arcuate nucleus has a well-established role in the detection and integration of long- and short-term blood-borne signals of hunger and satiety. Arcuate neurones integrate these signals and project to other hypothalamic areas involved in the control of energy balance such as the PVN and VMH [66]. Since early lesioning studies, the VMH has been thought to have a key executive role in feeding behaviour, possibly as the central executor of satiety. The VMH expresses receptors for ghrelin, leptin and orexin, is strongly affected by systemic administration of the satietyinducing gut peptide cholecystokinin (CCK), and projects to numerous hypothalamic and extra-hypothalamic centres such as the arcuate, the PVN and the NAcc [67]. The VMH is sensitive to activation of the major ascending satiety pathway from the vagus nerve to the nucleus of the solitary tract (NTS) [68,69].

In addition to potential effects on the metabolic control of appetite, vasopressin and oxytocin are powerful modulators of social behaviour in rodents [70] and humans [71]. One 
of the most striking examples is the attribution of behavioural differences between the closely related monogamous biparental prairie vole and the promiscuous asocial montane vole to differences in vasopressin V1a receptor expression throughout the brain [72]. In addition to pair bonding and parental behaviour (as well as aggression), oxy tocin and vasopressin can modulate most forms of social recognition behaviour such as recognition of familiarity, sexual receptiveness, hierarchy and relatedness. Intracerebroventricular administration of an oxytocin receptor antagonist weakens social recognition (measured by their exploratory behaviour towards younger rats) in adult female rats [73]. Similarly, oxytocin-knockout mice do not habituate to conspecifics [74].

Vasopressin and oxytocin are also involved in anxiety-related behaviour and thus present themselves as strong candidates as modulators of motivational behaviour. V1bRknockout mice have lower ACTH and corticosterone levels compared to wild types after experiencing stressors [75], and, although the anxiolytic effects of vasopressin and oxytocin are variable, it has been shown, using the elevated plus maze as a measure of anxiety-related behaviour, that administration of a V1a antagonist reduces anxiety [76]. Male V1bR-knockout mice display less anxiety-related behaviour than wild-type males when assessed by a number of measures including the elevated plus maze and the open field test [77]. The acute forced swim test is considered a good model of depression in rodents and is associated with increased ACTH levels. Forced swimming results in an increase in intrahypothalamic vasopressin release [78], indicating that increased vasopressin release may be involved in the onset or maintenance of depression in the model. Indeed, central administration of a V1aR antagonist during the forced swim test has an antidepressant effect demonstrated by an increase in the time spent struggling [79].

Oxytocin is generally considered to have anxiolytic effects but these can sometimes be difficult to distinguish from pro-social behaviours [56]. Nevertheless, central administration of oxytocin attenuates corticosterone release in response to a noise stress in rats and proves to be anxiolytic in the elevated plus maze test [80]. Oxytocin may also be involved in depression: the neuropeptide is antidepressive in the forced swim test; the reduction in immobility being dependent on the dose and duration of treatment [81].

In humans clear gender differences exist in the amounts and distribution of adipose tissue; women tend to have more adipose tissue and less lean mass than men, and women are more prone to obesity. The hypothalamic appetite-regulating circuits express high densities of receptors for the ovarian hormones oestrogen and progesterone, and deletion of the ER $\alpha$ oestrogen receptor gene leads to obesity [82]. However, the mechanistic implications are little studied. In several rodent models of targeted inactivation of specific genes implicated in appetite regulation, there is a gender difference in body weight phenotype. As described above, male transgenic mice deficient in the receptor for oxytocin are obese while females remain within a normal weight range but are prone to diet-induced obesity [62]. One interpretation is that in females, the rewarding aspects of food are a greater determinant of intake than in males, which respond more strongly to the loss of a component of satiety signalling.

\section{Questions and Objectives}

We hypothesise that neuropeptides involved in the stress response (particularly vasopressin and oxytocin) have effects on the responsiveness of neurons in the appetite-regulating regions of the hypothalamus to appetite-related stimuli such as leptin and ghrelin. We also predict that neurones which regulate eating behaviour will be affected by mediators of reward and mood such as opioids, cannabinoids and serotonin, and that effects of stress- 
and reward-mediating neurotransmitters may differ between males and females. Indeed, it is well-recognised that gender differences are seen in the stress response [83]. Gender differences in brain region activation have also been reported in hedonic responses to visual food stimuli in humans [84]. Certain eating disorders proposed to involved reward dysregulation (such as anorexia nervosa) have a unequal distribution between the sexes, with the prevalence among women being markedly higher [85].

The importance of the pre-and perinatal environment must also be considered. Maternal diet-induced obesity in rats results in offspring that are obese and hyperphagic [86], and early overfeeding of rats hastens the development of diet-induced leptin resistance [87]. Furthermore, offspring of rats that experienced variable swim, restraint and social stresses during pregnancy have larger fat stores, are hyperleptinaemic and insulin-resistant and are more susceptible to diet-induced obesity even when their mothers were not fed a high-fat diet during pregnancy [88].

There are major gaps in our knowledge and understanding, and current research is directed at filling these, with specific objectives that include:

i) To establish the effects of stress-related neuropeptides (oxy tocin and vasopressin) on neuronal pathways that regulate food intake.

ii) To establish the effects of reward-related neurotransmitters (opioids and cannabinoids) on neuronal pathways that regulate food intake.

iii) To determine the neural substrates within the reward and stress pathways that respond to neuropeptide modulators of food intake.

iv) To establish the effects of ovarian steroids (oestrogen and progesterone) on neuronal pathways that regulate food intake.

v) To characterise the mechanisms underlying chronic changes in metabolism after prenatal stress and/or maternal obesity.

\section{How Science Can Inform Health Policy}

New information regarding the neurobiological response to obesogenic food and its regulation by brain areas involved in reward, stress and mood, as well as by environmental cues and metabolic hormones, is important for informing policy at many levels. For example, the idea that food potentially has addictive properties can reinforce advice on nutrition and diet that certain foods and combinations of food not only have a caloric value but also that increased consumption of them increases risk of obesity through enhancing food addiction. Those informing policy within the food industry face the challenge of producing healthy rewarding foods. Finally, the research area has considerable opportunity to influence policy within the pharmaceutical sector, for which drugs targeting key emerging neurobiological targets without adverse effects on related neurobiological mechanisms must be given urgent priority.

\section{Acknowledgements}

The research leading to these results has received funding from the European Community's Seventh FrameworkProgramme(FP7/2007-2013undergrantagreementn²45009andFP7-HEALTH-2009-241592). The research was also supported by the Swedish Medical Research Council (2006-5663, 2009-5266), Novo Nordisk Fonden (GeA/AIR), ALF Göteborg (SU7601) and the Swedish Foundation for Strategic Research to the Sahlgrenska Center for Cardiovascular and Metabolic Research (A305-188). None of these grantawarding bodies had a role in study design, in the collection, analysis and inter pretation of the data, in the writing of the report or in the decision to submit the paper for publication. 


\section{Disclosure Statement}

The authors report no conflicts of interest.

\section{References}

1 Kipping RR, Jago R, Lawlor DA: Obesity in children. Part 1: epidemiology, measurement, risk factors, and screening. BMJ 2008;337:922-927.

2 Lake A, Townshend T: Obesogenic environments: exploring the built and food environments. J R Soc Promot Health 2006;126:262-267.

- 3 Suzuki K, Simpson KA, Minnion JS, Shillito JC, Bloom SR: The role of gut hormones and the hypothalamus in appetite regulation. Endocr J 2010;57:359-372.

- 4 Farooqi IS, O'Rahilly S: Mutations in ligands and receptors of the leptin-melanocortin pathway that lead to obesity. Nat Clin Pract Endocrinol Metab 2008;4:569-577.

- 5 Stanley BG, Kyrkouli SE, Lampert S, Leibowitz SF: Neuropeptide Y chronically injected into the hypothalamus: a powerful neurochemical inducer of hyperphagia and obesity. Peptides 1986;7:1189-1192.

- 6 Erickson JC, Clegg KE, Palmiter RD: Sensitivity to leptin and susceptibility to seizures of mice lacking neuropeptide Y. Nature 1996;381:415-421.

7 Qian S, Chen H, Weingarth D, Trumbauer ME, Novi DE, Guan X, Yu H, Shen Z, Feng Y, Frazier E, Chen A, Camacho RE, Shearman LP, Gopal-Truter S, MacNeil DJ, Van der Ploeg LH, Marsh DJ: Neither agouti-related protein nor neuropeptide $Y$ is critically required for the regulation of energy homeostasis in mice. Mol Cell Biol 2002;22:5027-5035.

- 8 Gropp E, Shanabrough M, Borok E, Xu AW, Janoschek R, Buch T, Plum L, Balthasar N, Hampel B, Waisman A, Barsh GS, Horvath TL, Brüning JC: Agouti-related peptide-expressing neurons are mandatory for feeding. Nat Neurosci 2005;8:1289-1291.

9 Caquineau C, Leng G, Guan XM, Jiang M, Van der Ploeg L, Douglas AJ: Effects of alpha-melanocyte-stimulating hormone on magnocellular oxytocin neurones and their activation at intromission in male rats. J Neuroendocrinol 2006;18:685-691.

10 de Kloet ER, Joëls M, Holsboer F: Stress and the brain: from adaptation to disease. Nat Rev Neurosci 2005; 6:463-475.

-11 Martí 0, Martí J, Armario A: Effects of chronic stress on food intake in rats: influence of stressor intensity and duration of daily exposure. Physiol Behav 1994;55:747-753.

12 Bell ME, Bhatnagar S, Liang J, Soriano L, Nagy TR, Dallman MF: Voluntary sucrose ingestion, like corticosterone replacement, prevents the metabolic deficits of adrenalectomy. J Neuroendocrinol 2000;12:461470.

13 Boggiano MM, Chandler PC, Viana JB, Oswald KD, Maldonado CR, Wauford PK: Combined dieting and stress evoke exaggerated responses to opioids in binge-eating rats. Behav Neurosci 2005;119:1207-1214.

14 Rowland NE, Antelman SM: Stress-induced hyperphagia and obesity in rats: a possible model for understanding human obesity. Science 1976;191:310-312.

-15 Tamashiro KL, Nguyen MM, Ostrander MM, Gardner SR, Ma LY, Woods SC, Sakai RR: Social stress and recovery: implications for body weight and body composition. Am J Physiol Regul Integr Comp Physiol.2007; 293:R1864-1874.

-16 Tamashiro KL, Hegeman MA, Sakai RR: Chronic social stress in a changing dietary environment. Physiol Behav 2006;89:536-542.

17 Berridge KC: 'Liking' and 'wanting' food rewards: brain substrates and roles in eating disorders. Physiol Behav 2009;97:537-550.

18 Blundell JE, Stubbs RJ, Golding C, Croden F, Alam R, Whybrow S, Le Noury J, Lawton CL: Resistance and susceptibility to weight gain: individual variability in response to a high-fat diet. Physiol Behav 2005;86: 614-622.

-19 Palmiter RD: Is dopamine a physiologically relevant mediator of feeding behavior? Trends Neurosci 2007; 30:375-381.

20 Maldonado-Irizarry CS, Swanson CJ, Kelley AE: Glutamate receptors in the nucleus accumbens shell control feeding behavior via the lateral hypothalamus. J Neurosci 1995;15:6779-6788.

-21 Rada P, Avena NM, Hoebel BG: Daily bingeing on sugar repeatedly releases dopamine in the accumbens shell. Neuroscience 2005;134:737-744.

22 Volkow ND, Wang GJ, Telang F, Fowler JS, Thanos PK, Logan J, Alexoff D, Ding YS, Wong C, Ma Y, Pradhan K: Low dopamine striatal D2 receptors are associated with prefrontal metabolism in obese subjects: possible contributing factors. Neuroimage 2008;42:1537-1543.

-23 Goldfield GS, Lorello C, Doucet E: Methylphenidate reduces energy intake and dietary fat intake in adults: a mechanism of reduced reinforcing value of food? Am J Clin Nutr 2007;86:308-315.

24 Johnson PM, Kenny PJ: Dopamine D2 receptors in addiction-like reward dysfunction and compulsive eating in obese rats. Nat Neurosci 2010;13:635-641. 
25 Zhou QY, Palmiter RD: Dopamine-deficient mice are severely hypoactive, adipsic, and aphagic. Cell 1995; 83:1197-1209.

-26 Kobayashi M, Iaccarino C, Saiardi A, Heidt V, Bozzi Y, Picetti R, Vitale C, Westphal H, Drago J, Borrelli E: Simultaneous absence of dopamine D1 and D2 receptor-mediated signaling is lethal in mice. Proc Natl Acad Sci U S A 2004;101:11465-11470.

27 Zigman JM, Jones JE, Lee CE, Saper CB, Elmquist JK: Expression of ghrelin receptor mRNA in the rat and the mouse brain. J Comp Neurol 2006;494:528-548.

28 Jerlhag E, Egecioglu E, Dickson SL, Douhan A, Svensson L, Engel JA: Ghrelin administration into tegmental areas stimulates locomotor activity and increases extracellular concentration of dopamine in the nucleus accumbens. Addict Biol 2007;12:6-16.

29 Abizaid A, Liu ZW, Andrews ZB, Shanabrough M, Borok E, Elsworth JD, Roth RH, Sleeman MW, Picciotto MR, Tschöp MH, Gao XB, Horvath TL: Ghrelin modulates the activity and synaptic input organization of midbrain dopamine neurons while promoting appetite. J Clin Invest 2006;116:3229-3239.

-30 Egecioglu E, Jerlhag E, Salomé N, Skibicka KP, Haage D, Bohlooly-Y M, Andersson D, Bjursell M, Perrissoud D, Engel JA, Dickson SL: Ghrelin increases intake of rewarding food in rodents. Addict Biol 2010;15:304311.

-31 Skibicka KP, Hansson C, Egecioglu E, Dickson SL: Role of ghrelin in food reward: impact of ghrelin on sucrose self-administration and mesolimbic dopamine and acetylcholine receptor gene expression. Addict Biol 2012;17:95-107.

-32 Perello M, Sakata I, Birnbaum S, Chuang JC, Osborne-Lawrence S, Rovinsky SA, Woloszyn J, Yanagisawa M, Lutter M,Zigman JM: Ghrelin increases the rewarding value of high-fat diet in an orexin-dependent manner. Biol Psychiatry 2010;67:880-886.

-33 Jerlhag E, Egecioglu E, Landgren S, Salomé N, Heilig M, Moechars D, Datta R, Perrissoud D, Dickson SL, Engel JA: Requirement of central ghrelin signaling for alcohol reward. Proc Natl Acad Sci U S A 2009;106:1131811323.

34 Jerlhag E, Egecioglu E, Dickson SL, Engel JA: Ghrelin receptor antagonism attenuates cocaine- and amphetamine-induced locomotor stimulation, accumbal dopamine release, and conditioned place preference. Psychopharmacology (Berl) 2010;211:415-422.

-35 Kawahara Y, Kawahara H, Kaneko F, Yamada M, Nishi Y, Tanaka E, Nishi A: Peripherally administered ghrelin induces bimodal effects on the mesolimbic dopamine system depending on food-consumptive states. Neuroscience 2009;161:855-864.

-36 Figlewicz DP, Evans SB, Murphy J, Hoen M, Baskin DG: Expression of receptors for insulin and leptin in the ventral tegmental area/substantia nigra (VTA/SN) of the rat. Brain Res 2003;964:107-115.

-37 Krügel U, Schraft T, Kittner H, Kiess W, Illes P: Basal and feeding-evoked dopamine release in the rat nucleus accumbens is depressed by leptin. Eur J Pharmacol 2003;482:185-187.

-38 Leinninger GM, Jo YH, Leshan RL, Louis GW, Yang H, Barrera JG, Wilson H, Opland DM, Faouzi MA, Gong Y, Jones JC, Rhodes CJ, Chua S Jr, Diano S, Horvath TL, Seeley RJ, Becker JB, Münzberg H, Myers MG Jr: Leptin acts via leptin receptor-expressing lateral hypothalamic neurons to modulate the mesolimbic dopamine system and suppress feeding. Cell Metab 2009;10:89-98.

-39 Fulton S, Richard D, Woodside B, Shizgal P: Food restriction and leptin impact brain reward circuitry in lean and obese Zucker rats. Behav Brain Res 2004;155:319-329.

40 Davis JF, Choi DL, Schurdak JD, Fitzgerald MF, Clegg DJ, Lipton JW, Figlewicz DP, Benoit SC: Leptin regulates energy balance and motivation through action at distinct neural circuits. Biol Psychiatry 2011;69:668674.

-41 Kristenssson E, Sundqvist M, Astin M, Kjerling M, Mattsson H, Dornonville de la Cour C, Håkanson R, Lindström E: Acute psychological stress raises plasma ghrelin in the rat. Regul Pept 2006;134:114-117.

-42 Asakawa A, Inui A, Kaga T, Yuzuriha H, Nagata T, Fujimiya M, Katsuura G, Makino S, Fujino MA, Kasuga M: A role of ghrelin in neuroendocrine and behavioral responses to stress in mice. Neuroendocrinology 2001; 74:143-147.

-43 Tung YL, Hewson AK, Dickson SL: Glucocorticoid-dependent stimulation of adiposity and appetite by a ghrelin mimetic in the rat. Eur J Endocrinol 2004;150:905-911.

-44 Carlini VP, Monzón ME, Varas MM, Cragnolini AB, Schiöth HB, Scimonelli TN, de Barioglio SR: Ghrelin increases anxiety-like behavior and memory retention in rats. Biochem Biophys Res Commun 2002;299: 739-743.

45 Carlini VP, Varas MM, Cragnolini AB, Schiöth HB, Scimonelli TN, de Barioglio SR: Differential role of the hippocampus, amygdala, and dorsal raphe nucleus in regulating feeding, memory, and anxiety-like behavioral responses to ghrelin. Biochem Biophys Res Commun 2004;313:635-641.

-46 Kanehisa M, Akiyoshi J, Kitaichi T, Matsushita H, Tanaka E, Kodama K, Hanada H, Isogawa K: Administration of antisense DNA for ghrelin causes an antidepressant and anxiolytic response in rats. Prog Neuropsychopharmacol Biol Psychiatry 2006;30:1403-1407.

-47 Lutter M, Sakata I, Osborne-Lawrence S, Rovinsky SA, Anderson JG, Jung S, Birnbaum S, Yanagisawa M, ElmquistJK, Nestler EJ, Zigman JML: The orexigenic hormone ghrelin defends against depressive symptoms of chronic stress. Nat Neurosci 2008;11:752-753. 
-48 Hansson C, Haage D, Taube M, Egecioglu E, Salomé N, Dickson SL: Central administration of ghrelin alters emotional responses in rats: behavioural, electrophysiological and molecular evidence. Neuroscience 2011;180:201-211.

-49 Heiman ML, Ahima RS, Craft LS, Schoner B, Stephens TW, Flier JS: Leptin inhibition of the hypothalamicpituitary-adrenal axis response to stress. Endocrinology 1997;138:3859-3863.

-50 Bornstein SR, Uhlmann K, Haidan A, Ehrhart-Bornstein M, Scherbaum WA: Evidence for a novel peripheral action of leptin as a metabolic signal to the adrenal gland: leptin inhibits cortisol release directly. Diabetes 1997;46:1235-1238.

-51 Guillaume-Gentil C, Rohner-Jeanrenaud F, Abramo F, Bestetti GE, Rossi GL, Jeanrenaud B: Abnormal regulation of the hypothalamo-pituitary-adrenal axis in the genetically obese fa/fa rat. Endocrinology 1990; 126:1873-1879.

52 Miell JP, Englaro P, Blum WF: Dexamethasone induces an acute and sustained rise in circulating leptin concentrations in normal human subjects. Horm Metab Res 1996;28:704-707.

-53 Nye EJ, Bornstein SR, Grice JE, Tauchnitz R, Hockings GI, Strakosch CR, Jackson RV, Torpy DJ: Interactions between the stimulated hypothalamic-pituitary-adrenal axis and leptin in humans. J Neuroendocrinol 2000;12:141-145.

54 Morimoto I, Yamamoto S, Kai K, Fujihira T, Morita E, Eto S: Centrally administered murine-leptin stimulates the hypothalamus-pituitary-adrenal axis through arginine-vasopressin. Neuroendocrinology 2000;71: 366-374.

55 Aguilera G, Subburaju S, Young S, Chen J: The parvocellular vasopressinergic system and responsiveness of the hypothalamic pituitary adrenal axis during chronic stress. Prog Brain Res 2008;170:29-39.

-56 Leng G, Onaka T, Caquineau C, Sabatier N, Tobin VA, Takayanagi Y: Oxytocin and appetite. Prog Brain Res 2008;170:137-151.

57 Kublaoui BM, Gemelli T, Tolson KP, Wang Y, Zinn AR: Oxy tocin deficiency mediates hyperphagic obesity of Sim1 haploinsufficient mice. Mol Endocrinol 2008;22:1723-1734.

58 Tung YC, Ma M, Piper S, Coll A, O’Rahilly S, Yeo GS: Novel leptin-regulated genes revealed by transcriptional profiling of the hypothalamic paraventricular nucleus. J Neurosci 2008;28:12419-12426.

-59 Shor-Posner G, Azar AP, Insinga S, Leibowitz SF: Deficits in the control of food intake after hypothalamic paraventricular nucleus lesions. Physiol Behav 1985;35:883-890.

-60 Aoyagi T, Birumachi J, Hiroyama M, Fujiwara Y, Sanbe A, Yamauchi J, Tanoue A: Alteration of glucose homeostasis in V1a vasopressin receptor-deficient mice. Endocrinology 2007;148:2075-2084.

61 Lokrantz CM, Uvnäs-Moberg K, Kaplan JM: Effects of central oxytocin administration on intraoral intake of glucose in deprived and nondeprived rats. Physiol Behav 1997;62:347-352.

62 Takayanagi Y, Kasahara Y, Onaka T, Takahashi N, Kawada T, Nishimori K: Oxytocin receptor-deficient mice developed late-onset obesity. Neuroreport 2008;19:951-955.

63 Mitra A, Gosnell BA, Schiöth HB, Grace MK, Klockars A, Olszewski PK, Levine AS: Chronic sugar intake dampens feeding-related activity of neurons synthesizing a satiety mediator, oxytocin. Peptides 2010;31: 1346-1352.

64 Olszewski PK, Klockars A, Olszewska AM, Fredriksson R, Schiöth HB, Levine AS: Molecular, immunohistochemical, and pharmacological evidence of oxytocin's role as inhibitor of carbohydrate but not fat intake. Endocrinology 2010;151:4736-4744.

-65 Lukas M, Bredewold R, Neumann ID, Veenema AH: Maternal separation interferes with developmental changes in brain vasopressin and oxytocin receptor binding in male rats. Neuropharmacology 2010;58: 78-87.

66 Bouret SG, Draper SJ, Simerly RB: Formation of projection pathways from the arcuate nucleus of the hypothalamus to hypothalamic regions implicated in the neural control of feeding behavior in mice. J. Neurosci 2004;24:2797-2805.

67 McClellan KM, Parker KL, Tobet S: Development of the ventromedial nucleus of the hypothalamus. Front Neuroendocrinol 2006;27:193-209.

68 Sabatier N, Leng G: Presynaptic actions of endocannabinoids mediate alpha-MSH-induced inhibition of oxytocin cells. Am J Physiol Regul Integr Comp Physiol 2006;290:R577-584.

69 Sabatier N, Leng G: Responses to cholecystokinin in the ventromedial nucleus of the rat hypothalamus in vivo. Eur J Neurosci 2010;31:1127-1135.

70 Veenema AH, Neumann ID: Central vasopressin and oxy tocin release: regulation of complex social behaviours. Prog Brain Res 2008;170:261-276.

71 Donaldson ZR, Young LJ: Oxytocin, vasopressin, and the neurogenetics of sociality. Science 2008;322:900904.

72 Young KA, Gobrogge KL, Liu Y, Wang Z: The neurobiology of pair bonding: insights from a socially monogamous rodent. Front Neuroendocrinol 2011;32:53-69.

73 Engelmann M, Ebner K, Wotjak CT, Landgraf R: Endogenous oxytocin is involved in short-term olfactory memory in female rats. Behav Brain Res 1998;90:89-94.

74 Ferguson JN, Young LJ, Hearn EF, Matzuk MM, Insel TR, Winslow JT: Social amnesia in mice lacking the oxytocin gene. Nat Genet 2000;25:284-288.

75 LolaitSJ, Stewart LQ, Jessop DS, Young WS, O'Carroll AM: The hy pothalamic-pituitary-adrenal axis response to stress in mice lacking functional vasopressin V1b receptors. Endocrinology 2007;148:849-856. 
-76 Engelmann M, Wotjak CT, Ebner K, Landgraf R: Behavioural impact of intraseptally released vasopressin and oxytocin in rats. Exp Physiol 2000;85:125S-130S.

-77 Bielsky IF, Hu SB, Szegda KL, Westphal H, Young LJ: Profound impairment in social recognition and reduction in anxiety-like behavior in vasopressin V1a receptor knockout mice. Neuropsychopharmacology 2004;29: 483-493.

-78 Wotjak CT, Ganster J, Kohl G, Holsboer F, Landgraf R, Engelmann M: Dissociated central and peripheral release of vasopressin, but not oxytocin, in response to repeated swim stress: new insights into the secretory capacities of peptidergic neurons. Neuroscience 1998;85:1209-1222.

-79 Ebner K, Wotjak CT, Landgraf R, Engelmann M: Forced swimming triggers vasopressin release within the amygdala to modulate stress-coping strategies in rats. Eur J Neurosci 2002;15:384-388.

-80 Windle RJ, Shanks N, Lightman SL, Ingram CD: Central oxytocin administration reduces stress-induced corticosterone release and anxiety behavior in rats. Endocrinology 1997;138:2829-2834.

81 Arletti R, Bertolini A: Oxy tocin acts as an antidepressant in two animal models of depression. Life Sci 1987; 41:1725-1730.

82 Brown LM, Gent L, Davis K, Clegg DJ: Metabolic impact of sex hormones on obesity. Brain Res 2010;1350: 77-85.

83 Luine V: Sex differences in chronic stress effects on memory in rats. Stress 2002;5:205-216.

84 Cornier MA, Salzberg AK, Endly DC, Bessesen DH, Tregellas JR: Sex-based differences in the behavioral and neuronal responses to food. Physiol Behav 2010;99:538-543.

-85 Kaye WH, Fudge JL, Paulus M: New insights into symptoms and neurocircuit function of anorexia nervosa. Nat Rev Neurosci 2009;10:573-584.

-86 Kirk SL, Samuelsson AM, Argenton M, Dhonye H, Kalamatianos T, Poston L, Taylor PD, Coen CW: Maternal obesity induced by diet in rats permanently influences central processes regulating food intake in offspring. PLoS One 2009;4(6):e5870.

87 Glavas MM, Kirigiti MA, Xiao XQ, Enriori PJ, Fisher SK, Evans AE, Grayson BE, Cowley MA, Smith MS, Grove KL; Early overnutrition results in early-onset arcuate leptin resistance and increased sensitivity to high-fat diet. Endocrinology 2010;151:1598-1610.

88 Tamashiro KL, Moran TH: Perinatal environment and its influences on metabolic programming of offspring. Physiol Behav 2010;100:560-566. 